\title{
Corporate Social Responsibility Contribution to Environmental Sustainability in Developing Countries: The Accountability Perspective
}

\author{
Mfon Solomon Jeremiah ${ }^{1}$ \\ ${ }^{1}$ De Montfort University, Leicester, UK \\ Correspondence: Mfon Solomon Jeremiah, Leicester Business School, De Montfort University, Leicester, UK. \\ E-mail: mfon.jerry@gmail.com
}

Received: November 20, 2017

Accepted: December 18, 2017

Online Published: December 20, 2017

doi:10.5539/ijbm.v13n1p33

URL: https://doi.org/10.5539/ijbm.v13n1p33

\begin{abstract}
There is a growing concern that voluntary CSR policy is almost incapable of enhancing the envisaged sustainable development in developing countries. The argument is about commitment to its implementation and its contribution to sustainable development, particularly in developing countries characterised by weak state institutions and governance. The present article examines the role which accountability could play in boosting CSR initiatives contribution to environmental sustainability in developing countries. It indicates when the need for accountability perspective of CSR (APCSR) arises, and its role in enhancing CSR contribution to environmental sustainability. The conceptual framework for applicability of APCSR is highlighted and discussed. The study provides the foundation for CSR policy development and empirical investigation of alternative approach to CSR practices in developing countries.
\end{abstract}

Keywords: corporate social responsibility, accountability perspective of CSR, environmental sustainability, developing countries, performance-based accountability, compliance-based accountability

\section{Introduction}

As corporate social responsibility (CSR) concept develops over the years, its scope and application has also expanded. CSR is conceptualised as a combination of multiple obligations of business to its stakeholders (Blowfield \& Frynas, 2005; Idemudia, 2008). There are various arguments on how business could use CSR initiatives to contribute to sustainable development (Simon, Powers \& Gunnermann, 1993; Windsor, 2001; Garriga \& Mele', 2004; Grant, 2008; Carroll \& Shabana 2010). Although scholars have proposed diverse drivers of such initiatives, two contrasting perspectives that dominate the discussion are the moral and the strategic or economic drivers (Centidamar \& Husoy, 2007; Dhanesh, 2014).

From moral perspective businesses contribute to sustainable development because they consider it as 'the right thing to do' and they are motivated by intrinsic factors such as ethical values and moral judgment (Heugens \& Kaptein, 2008). The strategic perspective (or business case) suggests that businesses engage in CSR because of extrinsic motivators such as market and institutional pressures and because it generates benefits such as increased financial performance, employee commitment, and customer loyalty (Unerman \& O'Dwyer, 2007; McWilliams \& Siegel, 2001; Dhanesh, 2014). A third perspective suggests that businesses are motivated by a complex interplay of both intrinsic and extrinsic factors, a melding together of moral and strategic perspectives (Child \& Tsai, 2005; Dhanesh, 2014).

The starting point of the CSR discourse was the necessity of businesspeople operating their business with social conscience (Bowen, 1953). Therefore, Bowen defines CSR as the obligations of businessmen to pursue those policies, to make those decisions, or to follow those lines of action which are desirable in terms of the objectives and values of our society. This implies that the concern of Bowen was for businesspeople to be conscious of the potential negative impacts of their business proposals on the society. It was, and it is still considered as obligation, particularly where business exerts significant negative impacts on the society.

World Business Council for Sustainable Development (WBCSD) (2000) in defining CSR states that 'corporate social responsibility is the continuing commitment by business to behave ethically and contribute to economic development while improving the quality of life of the workforce and their families as well as the local 
community and the society at large' (p8). Again, ethical component of the responsibilities is encapsulated in the definition. There is need for corporations to be committed, continually, to sustainable economic development by improving the quality of life of the society in which they operate. They are also expected to avoid every action that would impoverish the society and hamper the envisaged sustainable development.

Another interesting definition is that of European Commission (2002) which defines CSR as a concept whereby companies integrate social and environmental concerns in their business operations and their interaction with their stakeholders on a voluntary basis. Specifically, Commission of the European Communities, identifies the need for companies to concerned, voluntarily, about the effects of their business operations on the society, environment and their stakeholders. However, the institutional forces of capitalism propelling forward business, the corporate reform, and the ideological matrix of economic rationality has transposed most gestures of voluntary perspective of CSR - including sustainability and stakeholder dialogue - into something of a farce (Fleming \& Jones, 2013). This seems to provide answer to why voluntary perspective of CSR could not mitigate or ameliorate the social and environmental damages associated with business activities (Idemudia, 2009). This invariably hampers the envisaged sustainable development.

Indeed, voluntarism has been at the centre of corporate social responsibility (CSR) debate presently (Stormer, 2003; Waddock \& Wettstein, 2005; Grant, 2008). Its non-mandatory perspective to corporate environmental sustainability makes it popular among firms, some governments and global development actors (Blowfiled and Frynas, 2005; Silberborn \& Warren, 2007). It indicates the scope of discretionary decision-making on CSR issues by firms and the absence of externally imposed compliance requirements (Burke \& Logsdon, 1996). However, commitment to its implementation and ways it drives environmental sustainability is debatable (Kolk et al., 1999; Roht-Arriaza, 2001). In real terms, sustainable development in the corporate mining context requires a 'commitment' to continuous environmental and socioeconomic improvement, from mineral exploration, through operation, to closure (Kolk et al, 1999; Jenkins and Yakovleva, 2006). Such commitment is lacking even where there are voluntary self-regulated codes of conduct (Kolk et al, 1999; Roht-Arriaza, 2001).

The failure of voluntarism in CSR practices has instigated the need for alternative approaches. Some support of regulatory CSR approach (Unerman \& O'Dwyer, 2007; Emoyan, 2008; Frynas 2012). Those holding this opinion see "big" business as the main constraint to sustainable development. They accuse big business of causing environmental and social deterioration. They demand strict regulation of corporate behaviour by national governments as well as an international corporate accountability convention. The regulation normally focuses on compliance with basic minimum requirements. One key advantage of CSR in this context is that it can help organisations to develop new and better environmental policies and practices (Frynas 2009).

Furthermore, Frederick et al, (1992) define CSR as a principle stating that corporations should be accountable for the effects of any of their actions on the community and environment. These are actions that could injure the community and the environment. The implication is that business should be sensitive to potential harms of its actions on various stakeholder groups (Freeman, 2001). Where business actions significantly affect the society, CSR is considered as means of rendering accountability to the affected society. Accountability emerges to redirect our attention to the aching question of corporate obligations to the society (Uting, 2008). Therefore, accountability perspective of CSR (APCSR) becomes relevant where business actions impact on the society negatively and voluntary CSR fails to mitigate such negative impacts.

Accountability is a broad concept, often used loosely, in explaining human behaviour in a specific relationship. Most often it is used in an abstract form. This makes it difficult to measure and predict its impact on the outcome of human action and behaviour. To address this problem, the author distinguishes accountability as a term used subjectively to judge others' actions from accountability based on factual justification of performance of predetermined objectives. It is the outcome of observed human behaviour in a relationship that determines the subjective judgement on whether the actors operated with the sense of accountaibility. On the other hand, it is the factual, justifiable, and satisfactory level of performance that determines whether the activities were performed with the sense of accountability by complying with the predetermined standards. The later involves standards setting, performance monitoring, deficient performance discountenance and compliance enforceability.

Two key elements of this form of accountability are performance and compliance (Burritt \& Welch, 1997; Carman, 2010). Performance-based accountability focuses on past activities, while compliance-based accountability is concerned with the future activities Therefore, the abstract form of accountability is based on subjective judgment while performance/compliance-based accountability is based objectively on facts. It is the role of this performance/compliance-based accountability in enhancing CSR contribution to environmental sustainability that is the focus of this study. 
Indeed, sustainability, corporate sustainability, sustainable development, CSR and corporate responsibility are terms used in studying the relationship of a corporation with a wider constituent of stakeholders (Roca \& Searcy, 2012). Some authors have noted that CSR and corporate sustainability are closely associated, while others believe there remains a subtle distinct between them (Roca \& Searcy, 2012). Others consider them as synonyms (van Marrewijk, 2003) and some argue that the two terms have converged to the very similar concepts of economic, social and environmental sustainability in recent years (Steurer et al., 2005). No matter the views, it is important to note that CSR captures these three dimensions of developments (economic, social and environmental). The three dimensions are often referred to as the "triple bottom line" of corporate sustainability (Elkington, 1998; Bansal, 2005; Roca \& Searcy, 2012).

The environmental component of sustainable development is neglected in most developing countries. Lozano (2008) asserts that in countries where basic human needs, such as food and shelter are not fulfilled attention is not given to environmental component of sustainable development. This seems true in most developing countries, including Nigeria. However, Dyllick \& Hockerts (2002) emphasise that sustainable development cannot be achieved where any of these components is not integrated into the programme. Therefore, the present study focuses on the environmental dimension of corporate sustainability.

Environmental dimension of sustainability is concerned with an organization's impacts on living and non-living natural systems, including ecosystems, land, air, and water (Global Reporting Initiative, 2014, Online). It revolves around the ways corporations explore the natural environment and the social effect of such environmental exploration in terms of pollution and degradation. When the CSR initiative is focused on environmental dimension of "triple bottom line" the outcome is considered corporate environmental performance, or CSR contribution to environmental sustainability (Russo \& Fouts, 1997; Bhattacharyya \& Cummings, 2015).

As Blowfield \& Frynas (2005) argue, we know very little about the impact of CSR initiatives in developing countries, and that even what we do know raises questions about both the efficiency of CSR approaches and the tangible benefits for the poor and marginalized communities. This calls for investigation of best CSR approach in the context of developing countries. Therefore, this study proposes APCSR as a better approach which would enhance CSR contribution to sustainable development. The framework draws its illustrations from Nigeria oil and gas industry in Niger Delta region. The questions the study is attempting to address are: a) why should MNCs adopt APCSR in developing countries? and b) how would APCSR be adopted by MNCs?

The remaining part of the paper discusses the contextual background of CSR and sustainability in Nigeria in section two, followed by the rationale for adopting of APCSR in section three. Section four presents a model of community-corporate accountability relationship. A detailed accountability framework, which attempts to answer how MNCs can adopt APCSR, is discussed in section five. This is followed by conclusion.

\section{CSR and Environmental Sustainability in Nigeria}

In Nigeria, what seems to drive CSR actions of multinational oil companies is the external pressure they received from some activists group. Oil MNCs are often confronted by the growing power of key stakeholder groups and the complex links between them (Boele et al., 2001). Given such pressure some of the MNCs started taking CSR actions. For instance, Shell has developed explicit models such as its 'Sustainable Development Management Framework' and the associated 'Road Map', which are designed to build in the stakeholder dimension to their CSR decision making (Boele et al., 2001; Aaron, 2012). The development of this framework as they point out is informed by the significant conflict between Shell and the Movement for the Survival of the Ogoni People (MOSOP) in middle 1990s. therefore, there is need to align CSR actions with the interests of all the stakeholders of corporations not only the shareholders.

The incidence of environmental pollution through oil spill as commonly seen in the oil and gas industry in Nigeria suggests the need for environmental policy review from both government and oil MNCs. Presently, the generic response to social/environmental impacts of oil spill in Nigeria is through voluntary perspective of CSR. Such approach does not change the environmental behaviour of oil MNCs regarding oil spill prevention and environmental pollution control. The demand for regulated CSR practices is informed by failure of firms' voluntary CSR approach to mitigate the environmental damages associated with their activities (Idemudia, 2009). It is argued that corporate voluntarism has been repeatedly shown to have failed to place the interests of non-owner stakeholders on a par with the pursuit of shareholder economic value (Laufer, 2003; Unerman \& O'Dwyer, 2007).

The failure of voluntarism is common where there is a weak legal system and poor state governance (Fagbohun, 2006). The point is that voluntary action is influenced by intention, and intention rises with phycological thought 
of benefit or negative repercussion of not taking an action. A weak legal system has no foreseeable negative consequences, which corporation could endeavour to avoid. Such legal system could be easily circumvented because it is characterised by corruption, injustice, undue delay of legal proceedings, distrust and general lack of enforceability of environmental regulations (Ross, 2004; Fagbohun, 2006; Kobonbaev \& Eicher, 2009). This makes environmental degradation inevitable.

Besides, environmental regulations in Nigeria are not coherent. This makes it difficult to interpret and implement. For instance,

Nigeria's environmental legislation especially as it is related to the oil and gas industry is fragmented as it consists of several legislative acts, regulations and decrees. Beyond this, several reviews of these laws have revealed problems that militate against the achievement of environmental sustainability, the primary objective of legislation (Emoyan, 2008; p32).

Another point of weakness of environmental legislation in Nigeria as well as other developing countries is that they may not have the capacity to effectively regulate a technically sophisticated industry such as the oil and gas sector; and formal regulatory approaches to environmental issues have often failed in developing countries (Frynas, 2012). For instance, the legal framework for the control and management of water pollution in Nigeria has been found to be totally inadequate. Several studies point to the lack of technical/institutional capacity among Nigerian government agencies for enforcing high environmental standards (Frynas 2010, Adedeji and Ako 2009). The outcome is unabated environmental degradation in Niger Delta region of Nigeria (Frynas, 2000; Fagbohun, 2006).

Indeed, the failure of legislation leads to deep seated distrust between government, regulatory agencies, petroleum industry operators and communities (Turner \& Brownhill, 2004). These culminate in a serious tension between oil companies and Niger Delta youths. The tension indicates that oil MNCs are considered to owe local communities some environmental obligations; they are required to respect human and property rights of the local communities; they are obliged to mitigate firm's social/environmental impacts of pollution; and they are subject to sanctions in cases of non-compliance. These issues cannot be addressed using voluntary CSR given the discussed weak Nigerian regulatory system. The scenario begs for alternative approach such as APCSR, which this article examines. As Uting (2008) explains, accountability emerges to address issues of public interest and corporate obligations.

\section{The Rationale for Accountability Perspective of CSR (APCSR)}

The terms mandatory CSR is sometimes discussed in literature interchangeably with state regulatory and accountability perspectives of CSR (Hamann, Acutt \& Kapelus 2003; Blowfield \& Frynas, 2005; Unerman \& O'Dwyer, 2007; Frynas, 2012; Ackers \& Eccles, 2015). Accountability differs from state regulatory perspective of CSR. Figure 1 captures three different perspectives of CSR: voluntary, regulatory and accountability. Voluntary is at the centre of the debate and the most celebrated in the developed economies. However, as mentioned in this study, it is considered a failure in most developing economies.

In addressing the inadequacy of voluntarism in developing economies, some advocate for regulatory CSR. For instance, new legislation has been passed in Ghana to require logging companies to secure a Social Responsibility Agreement with customary landowners. Besides, code of conducts by multinational firms incorporated into a contract with suppliers are becoming legally binding (Blowfield \& Frynas, 2005). This indicates a move towards regulating CSR practices. 


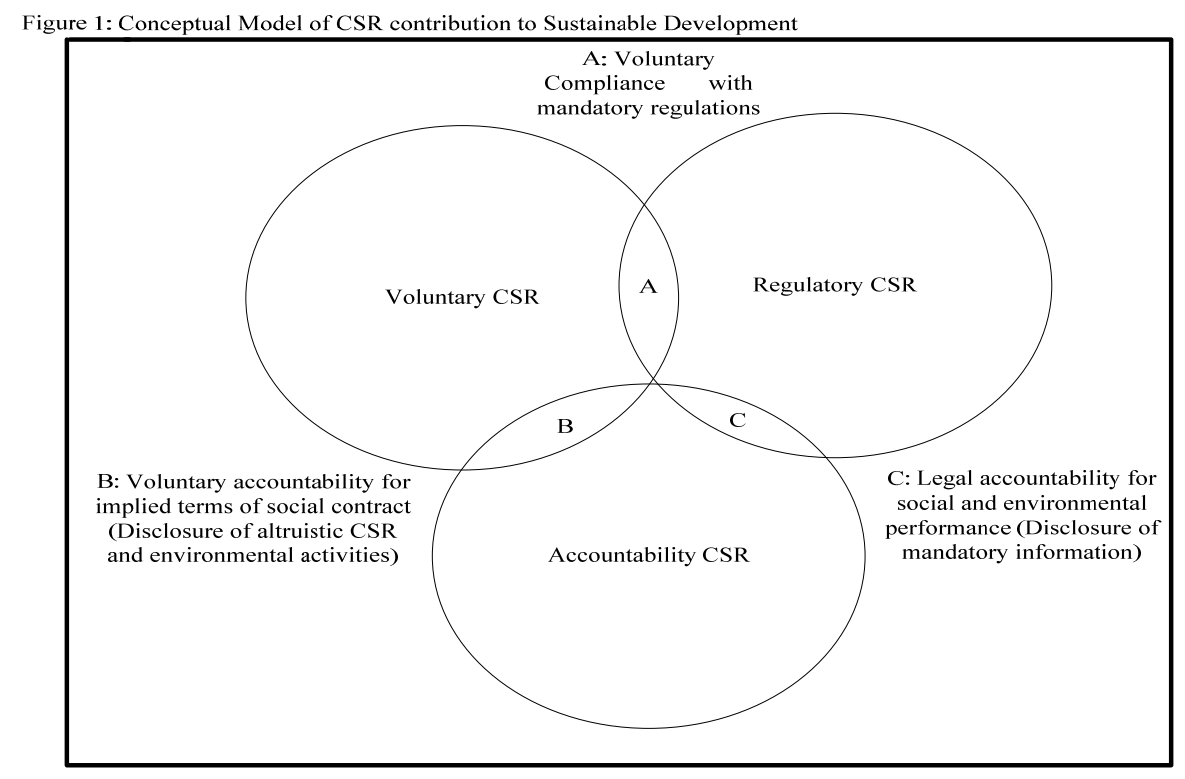

Source: Developed by the researcher

Accountability perspective of CSR is considered in the present study as a different concept from regulatory and voluntary CSR. Why accountability? What makes accountability more relevant in developing countries than voluntary and regulatory CSR? How could it be used in improving CSR contribution to environmental sustainability in in developing countries?

Firstly, accountability draws attention to corporate environmental obligations, human and property rights of the local communities, necessity of firm's social/environmental impacts mitigation, and sanctions in cases of non-compliance. In other words, accountability approach seeks answers to questions about corporate environmental obligations to the natives. Where a firm has failed in its ethical social and environmental obligations, voluntary CSR can hardly correct, satisfactorily, the wrongs done to the affected stakeholders. It is APCSR, which involves the participation of the affected stakeholders or their representatives in environmental management decision-making that would likely do. Secondly, accountability approach lays out the strategic structure which business could adopt in addressing social and environmental issues using CSR programmes.

The first aspect was discussed in previous section in the context of Nigeria's Niger Delta. In that section, the neglected corporate environmental obligations and the resultant community resistance are discussed. When people identify an instance of unfair treatment, as discussed in previous section, they are trying to hold someone accountable for an action (or inaction) that threatens another person's material or psychological well-being (Folger \& Cropanzano, 2001, p3). CSR policy could be geared towards amending the unfair condition.

The second aspect, which focuses on the operational structure of accountability, is henceforth examined. Accountability has two crucial components: 'it arises as a result of relationship between two or more parties ... and its nature is determined by the social and moral context in which the relationship is manifest' (Gray et al, 2014, p50). Such relationship has a moral dimension which is determined by the nature of the relationship, the actions expected and/or required in the relationship and the community context (Gray, 1992). One of such moral dimensions is to render the account, to explain oneself, to articulate one's intentions and aspirations, to offer detailed explanation of one's action. This is what is referred to as accountability (Gray et al, 2014). The relationship in the context of being accountable to local communities starts from the social contract that exists between the organisation and the society (Deegan, 2007). In real terms, commencing business within a society establishes an accountability relationship. More on community-corporate relationship is discussed later in the paper.

Moreover, two elements embedded in accountability are performance and compliance (Burritt \& Welch, 1997; Carman, 2010). This makes accountability to be divided into performance-based and compliance-based accountability. Performance-based accountability focuses on the outcomes and results of the past activities, while compliance-based accountability is concerned with laying down rules, processes and procedures which could guide future performance. This approach, most likely, will bring CSR programme into the mainstream corporate plans. 
Under accountability regime, CSR initiatives will likely be related closely with corporate undue externalities and those affected by such externalities. Firms will be expected to enter into agreement with the indigenous people as their stakeholders or their representatives (Neugebauer III, 2003) on the CSR initiatives that will ameliorate or mitigate social and environmental impacts of business on the society. The implication is that CSR programmes of firms will depend on the nature of environmental degradation associated with an industry. Pollution intensive industries will unavoidably spend more on CSR under accountability approach than voluntary. Huge CSR package will likely be reduced by firms through improved internal pollution control or prevention.

The challenge could be the implementation of the APCSR. As mentioned earlier, accountability involves two or more people. Therefore, environmental accountability makes room for direct engagement with stakeholders who can affect or are affected by business activities (Freeman, 1984; Clarkson, 1995). They are involved in setting the minimum environmental requirements and CSR programmes that would absorb the impact of unavoidable but significant environmental degradation. In other words, APCSR lays down minimum environmental requirements and programmes that will redress the impact of unavoidable environmental degradation. They are to participate in environmental decision making as well as compliance monitoring and enforceability. Moreover, a set of criteria upon which actual CSR initiatives and environmental performance could be evaluated are established in collaboration with the stakeholders or their representatives.

Figure 1 further indicates intersection of these three core perspectives. 'A' shows intersect of regulatory CSR with voluntary CSR. Within 'A' region there is a voluntary compliance with mandatory regulation. According to Blowfield \& Frynas (2005), many 'voluntary' initiatives also have a 'mandatory' aspect, and there are already many intersections between voluntary CSR and regulatory. The point is that firms voluntarily embark on corporate social and environmental responsibility because of some state legislative influence (Sharma 2001; Christman, 2004; López-Gamero et al., 2010). This is commonly seen in developed countries.

'B' region in Figure 1 shows where voluntary CSR overlaps with accountability. This is the case of voluntary accountability to indigenous poor communities. It demonstrates voluntary accountability for intentional actions. The impression is that the thought of justifying actions (or inactions) has the tendency to influence corporate managers' social and environmental responsiveness. Implication is that even though enforceability and answerability are two basic concepts of accountability theory (Schedler, 1999), the enforceability perspective remains dormant if business organisations voluntarily comply with both the terms of implied social contract and the endorsed terms of informed consent or environmental agreements (MacKay, 2004). This makes accountability implicit, especially with regards to intention to take an action (Lerner, \& Tetlock, 1999). Outside 'B' region accountability operates with its basic concepts and components.

'C' portrays legal accountability for social and environmental actions (Gray et al, 2014). Such accountability in U.S. environmental law is mostly associated with enforcement because of related regulatory programme (Paddock, 2004). As Paddock (2004) further explicates, accountability in the context of environment encompasses a wide range of mechanisms. It starts from enforcement to public participation in social and environmental issues. It also entails reporting to the public the environmental data. These activities expose the environmental behaviour of organisations and individuals to the public and thus create either a legal obligation to improve environmental behaviour or a stronger sense of responsibility to better-manage activities that would have environmental impacts.

The researcher believes that it is APCSR that could lead to improved sustainability in developing countries. The argument is that APCSR enables business to negotiate and enter into environmental agreements with the host communities or its representatives. The need for contractual agreements with communities is emphasised in Heugens \& Kaptein (2008). Such agreements are endorsed when an organisation presents its environmental impact assessment (EIA) to the host communities and seeks free, prior, and informed consent (FPIC) of the host communities before commencing a business project (MacKay, 2004; Laplante \& Spears, 2008). The approach is 'to seek a negotiated consensus through open and honest dialogue amongst affected parties' (Brown et al, 2015, p2).

This approach is different from the legislative environmental laws which sometimes are formulated with less or no interest of the affected stakeholders (marginalised poor communities) at heart. Such communities may not make any input to the regulatory framework (Emoyan, 2008; Edo, 2012). Their needs in such a case are not considered. Collier (2008), which empirically examines accountability of organizations to multiple stakeholders with differing interests and power, argues that there is, or at least should be, accountability to each of these stakeholders in terms of the organization's satisfaction of their economic, legal or moral obligations.

Unlike altruistic voluntary CSR approach, which non-compliance attracts no penalty, accountability uses 
enforceability mechanism, built into performance evaluation criteria (Dillard, 2007) and legalised informed consent document, to enforce compliance. Besides, environmental agreement is often seen as a stepping-stone to strict legal environmental law where corporations fail to voluntarily abide by this agreement (Khalastchi \& Ward, 1998). Another enforceability weapon available to poor and marginalised communities, where the legal and judiciary system are not helpful, is radicalism. This is a peaceful protest (Jallow 2009). As mentioned earlier, this has triggered oil MNCs' response to some aspect of social issues in Nigeria in the past (Idemudia, 2011).

\section{Community-Corporate Accountability Relationship}

The community-corporate accountability relationship is depicted in community-corporate accountability model captured in Figure 2. In the figure, firm is shown as a separate entity that generates environmental pollution, which affects the community. Although in most cases, firms are part of the community but for clarity it is represented as an external organisation. The community receives pollution and suffers the negative effect of it. From the figure, firm is bonded with the community through a social contractual and stakeholder relationship. Therefore community (accountee) demands for accountability for the effect of environmental and social issues caused by firm; while firm (accountor) renders accountability to the community for the environmental pollution associated with its business activities. Again, the issue of corporate environmental obligations emerges to support the stakeholders demand for accountability in this relationship.

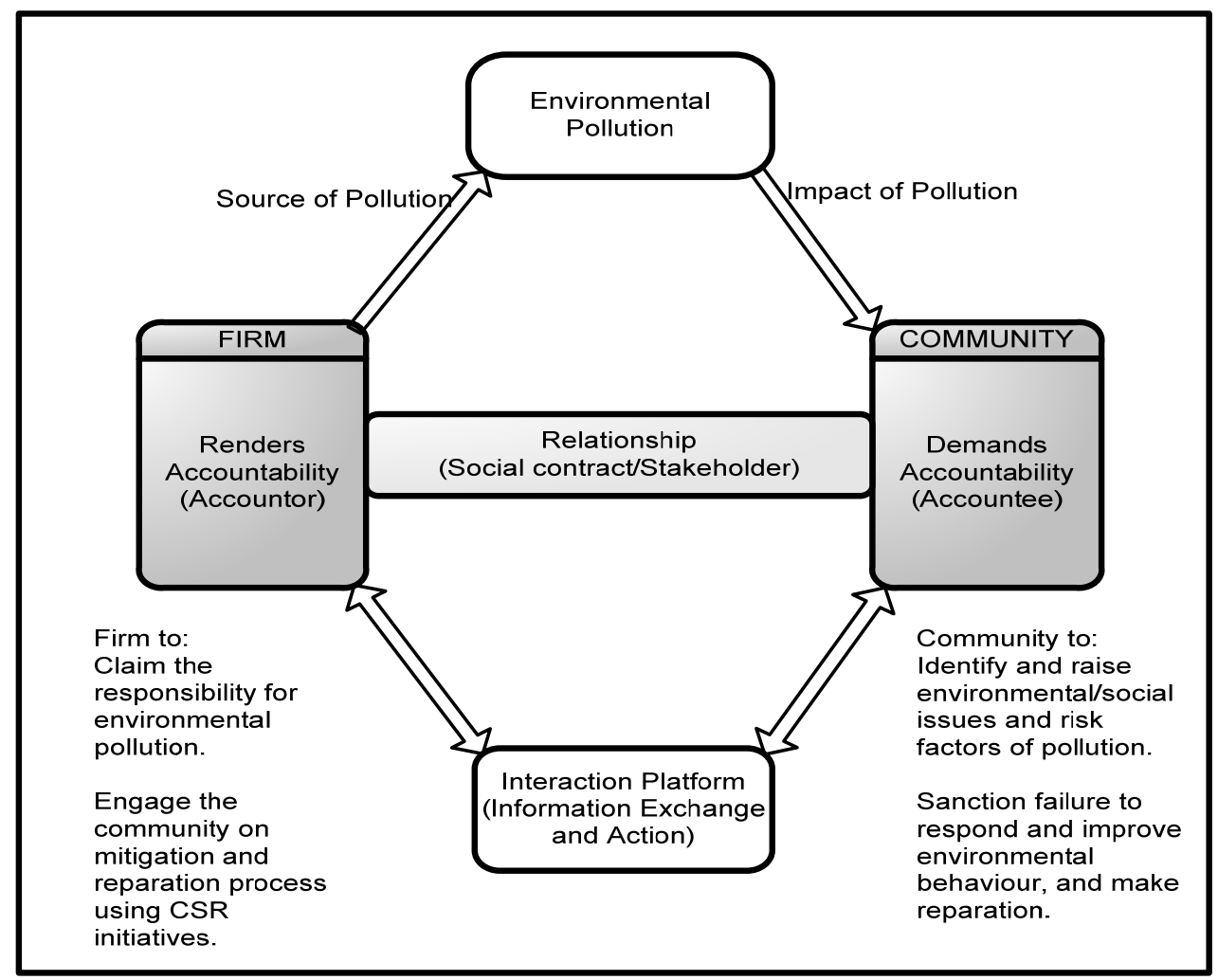

Source: Developed by the researcher

Figure 2. Community-Corporate Accountability Model

A viable accountability procedure would create an interactive platform. As shown in the diagram, such platform is where both parties exchange information and decides how to solve the environmental and social problems related to business activities. Information exchange is crucial in a sound system of accountability (Gray et al, 1996). The double headed arrows that link firm and community to interaction platform, respectively, show that negotiation is iterative. Industry specific environmental and social issues negotiated are further explicated in Table 1. The Table indicates possible issues the community would bring up for negotiation with the companies. It also presents the possible ways the companies would respond and negotiate with the local community. 
Table 1. Summary of Potential Corporation-Community Information Exchanged

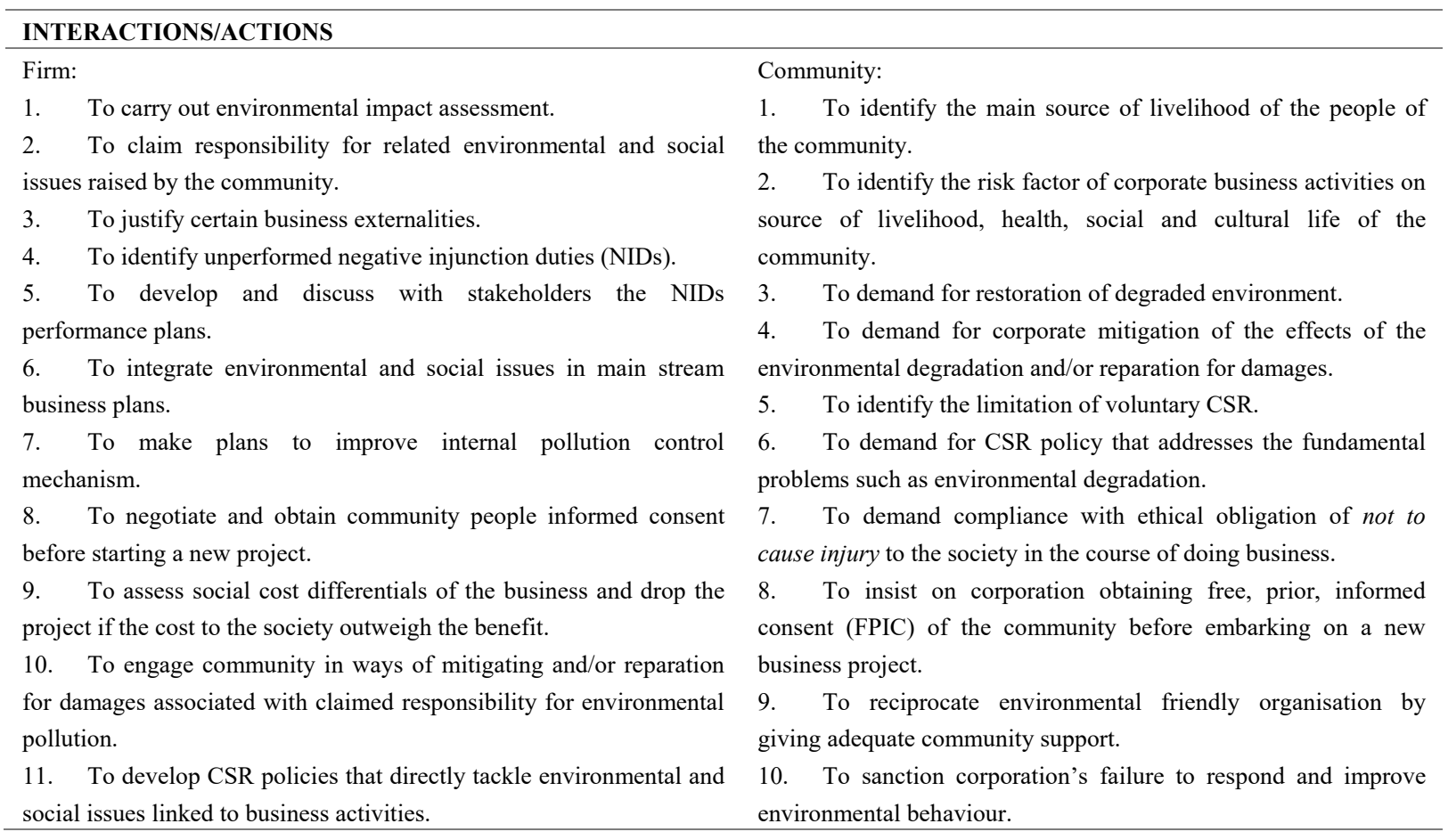

\section{Conceptual Framework for Applicability of APCSR}

Based on rationale for APCSR discussed, community-corporate relationship concept and possible interactions, a framework is developed to disclose how accountability approach to CSR can address the fundamental industrial-based environmental issues in developing countries. The framework points to things that are crucial in best CSR practice. These are:

a) Assessment of business environmental condition,

b) Assessment of the risk factor of environmental degradation,

c) Evaluation of the perceived social cost differentials,

d) Obtaining the indigenous Free, Prior and Informed Consent (FPIC),

e) Negotiating the expected improvement in CSR programmes,

These key issues are discussed in detail in this section.

\subsection{Assessment of Business Environmental Condition}

The accountability approach places emphasis on restoring, as much as possible, the affected environment to its original condition before undue pollution occurred. Of course, the essential principle contained in the actual notion of any illegal act is that reparation must, so far as possible, wipe out all the consequences of the illegal act and re-establish the situation which would, in all probability, have existed if that act had not been committed (Suzuki \& Nanwani, 2003). To establish whether corporate pollution has any serious effect on the host community, there must be adequate assessment of environmental condition by both firms and stakeholders. The focus of such assessment would be on corporate performance of, at least, its minimum environmental requirement. This principle needs be pursued as it would likely motivate corporation to improve their environmental policies, and thus reduce potential damages associated with industrial pollution.

\subsection{Assessment of the Risk Factor of The Environmental Pollution}

The nexus of potential environmental pollution risks to source of livelihood, health, social and cultural life of the local community should be adequately evaluated. A careful evaluation of the magnitude and the nature of the potential risks of industrial pollution provides a better understanding of what the host community is losing to business This identifies and links the environmental and social issues to a specific firm or industry that is responsible. Hence, CSR initiative of such firm ought to be directed toward solving problems it has created (Bowen, 2000). To address the environmental problem satisfactorily, the affected stakeholders should necessarily 
be involved in solution's decision-making process. This is possible under accountability approach.

\subsection{Evaluation of the Perceived Social Cost Differentials}

The benefits which community derive from the business operation should be weighed against what they are losing to business. Where what the community is losing is greater then what it gains from the business, then there is social cost differential (Heal, 2005). CSR policy should be geared toward balancing the community's benefit from business with the effect of the business on them. The accountability perspective of CSR puts the burden of balancing this social cost on the business. Therefore, perceived social cost differential ought to be a major determinant of CSR initiative content.

Voluntary CSR initiatives, which in most cases are embarked on with no reference to such private-social cost differentials have failed to address the effects of the cost differentials. This hinders the envisaged environmental sustainability (Heal, 2005; Idemudia, 2008). Given information exchange embedded in accountability process, there is possibility of identifying and aligning negative externalities (private costs) and their effects on community (social costs) thus establishing acceptable differentials, which could form basis of negotiating and embarking on CSR initiatives that could compensate for and/or mitigate such social cost differentials. Hence, corporate accountability mechanism is expected to provide input for dialogue for better CSR policies.

\subsection{Obtaining the Indigenous Free, Prior and Informed Consent (FPIC)}

At its initial stage of dialogue with the community, firms would have the opportunity to disclose the main advantages and disadvantages of their business proposal to the community and the community would consciously consent to or reject the proposed project. This an opportunity for community to have a good understanding of potential social impact of the business activities. Social impacts as Wawryk (2003) describes are the consequences to human populations of any public or private actions that alter the way in which people live, work, play, relate to one another, organise themselves to meet their needs, and generally cope as members of society. According to Wawryk (2003), the term also includes cultural impacts involving changes to the unique norms and beliefs that guide and rationalise their cognition of themselves and their society as distinguished from others.

From the argument, although fraught with contingencies and considerable need for empirical analysis, informed consent, encapsulated in accountability mechanisms, presents the obvious next step in the evolution of the relationship between businesses and communities. Informed consent has the potential to address the complex and dynamic root causes of community concern (Laplante \& Spears, 2008). It appears to be a feasible means of creating rapport between community and corporations.

\subsection{Negotiating the Expected Improvement in CSR Programmes}

Corporate improvement in environmental conduct is often expected when external stakeholders demonstrate their dissatisfaction on firms' level of pollution. Following the proposed change in the environmental management system, the expected improvement in the environmental sustainability should be negotiated with constituents of stakeholders. The improvement would be expected in terms of firms' commitment to the physical environmental sustainability. Such commitment would be reflected in three interconnected environmental management strategies - pollution prevention, product stewardship, and sustainable development (Hart, 1995). In other words, commitment demonstrates corporate practical concern with environmental wellbeing of the wider stakeholder by "integrating the "voice of environment," that is, external stakeholder perspectives, into product design and development processes' (Hart, 1995, p993). That is, what gives stakeholders environmental concern would be considered proactively when developing environmental management strategies.

\section{Conclusion}

In this study the researcher argues that APCSR would likely enhance corporate response to environmental issues. It is accountability regime that would likely draw the attention of MNCs to their ethical environmental obligations. The rationale of APCSR was discussed to explicate why MNCs could adopt accountability approach, particularly in developing countries. Further, the article argues that corporate environmental behaviour can be transformed, and environmental damages associated with industrial pollution reduced where firms adopt APCSR. In real terms, the accountability framework developed would likely enable corporate applicability of environmental sustainability principles in their core business activities. This answers the how question in this study. Where the environment is adequately sustained, the sustainable community development effort made by MNCs will have significant positive impact because the people's core source of livelihood (environment) will no longer be degraded.

Moreover, it is accountability that establishes the nexus of community's life and culture with corporate activities 
thus imposes the duty of care on corporations. Such duty of care cannot be left in the hands of corporations and their managers without adequate surveillance, given their profit maximisation motive, which in most cases defies morality and rationality (Unerman \& O'Dwyer, 2007; Hamann et al, 2003; Uhlmann, 2012). Hence, accountability approach points to another way of understanding how CSR policies of firms could benefit the local communities by enhancing MNCs' contributions to the envisaged environmental sustainability. It also demonstrates how corporations can reduce tension and communities' project resistance by engaging communities when making decisions on how to use CSR policies to mitigate negative impacts of their activities.

This is the first phase of this study. The second phase which concerns the empirical testing of this framework is ongoing. The data are being collected from three key environmental stakeholders - firms, local communities, and the government agencies. The focus is to establish whether APCSR can make any significant different in terms of enabling MNCs in developing countries to improve their environmental behaviour. As the weak legal framework inhibits environmental sustainability in developing countries, the study would seek to establish possible links of key accountability variables with corporate environmental performance. We also suggest that this conceptual framework be tested empirically in other developing countries by interested researchers.

\section{References}

Aaron K. K. (2012). New corporate social responsibility models for oil companies in Nigeria's delta region: What challenges for sustainability? Progress in Development Studies, 12(4), 259-273. http:/journals.sagepub.com/doi/abs/10.1177/146499341201200401

Ackers, B., \& Eccles, N. S. (2015). Mandatory corporate social responsibility assurance practices. Accounting, $\begin{array}{llll}\text { Auditing } \quad \& \quad \text { Accountability } & \text { Journal, } & \text { 28(4), } & \text { 515-550. }\end{array}$ http://www.emeraldinsight.com/doi/abs/10.1108/AAAJ-12-2013-1554

Blowfield, M., \& Frynas, J. G. (2005). Setting new agendas: Critical perspectives on Corporate Social Responsibility in the developing world. International Affairs, 81(3), 499-513.

Boele, R., Fabig, H., \& Wheeler, D. (2001a). Shell, Nigeria and the Ogoni. A study in unsustainable development I: the story of shell, Nigeria and the Ogoni people-environment, economy, relationships: conflicts and $\begin{array}{lllll}\text { prospect for } & \text { resolution. Sustainable Development, } & \text { 9, } & \text { 74-86. }\end{array}$ http://onlinelibrary.wiley.com/doi/10.1002/sd.161/full

Brown, J., Dillard, J. \& Hopper, T. (2015). Accounting, accountants and accountability regimes in pluralistic societies: taking multiple perspectives seriously. Accounting, Auditing \& Accountability Journal, 28(5). http://www.emeraldinsight.com/doi/abs/10.1108/AAAJ-03-2015-1996

Burke, L., \& Logsdon, J. (1996). How corporate social responsibility pays off. Long Range Planning, 29, 495-502.

Burritt, R. L., \& Welch, S. (1997). Accountability for environmental performance of the Australian Commonwealth public sector. Accounting, Auditing \& Accountability Journal, 10(4), 532-561. http://www.emeraldinsight.com/doi/abs/10.1108/09513579710367494

Carman, J. G. (2010). The accountability movement: What's wrong with this theory of change? Nonprofit and $\begin{array}{lllll}\text { Voluntary } & \text { Sector } & \text { Quarterly, } & 39(2), & \text { 256-274. }\end{array}$ http://journals.sagepub.com/doi/abs/10.1177/0899764008330622

Carroll, A. B., \& Shabana, K. M. (2010). The Business case for corporate social responsibility: A review of concepts, research and practice. International Journal of Management Review. http://onlinelibrary.wiley.com/doi/10.1111/j.1468-2370.2009.00275.x/full

Clarkson, M. E. (1995). A stakeholder framework for analyzing and evaluating corporate social performance. Academy of management review, 20(1), 92-117.

Collier, P. M. (2008). Stakeholder accountability: A field study of the implementation of a governance improvement plan. Accounting, Auditing \& Accountability Journal, 21(7), 933-954. http://www.emeraldinsight.com/doi/abs/10.1108/09513570810907429

Deegan, C. (2007). Organisational legitimacy as a motive for sustainability reporting. In Unerman, J., Bebbington, J. and O'Dwyer, B. (Eds.), Sustainability, Accounting and Accountability (pp. 127-149). Abingdon, Oxon: Routledge.

Dhanesh, G. S. (2014). Why Corporate Social Responsibility? An Analysis of Drivers of CSR in India. Management Communication Quarterly. http://journals.sagepub.com/doi/abs/10.1177/0893318914545496 
Dillard, J. F. (2007). Legitimating the social accounting project: An ethic of accountability. In Unerman, J., Bebbington, J. and O'Dwyer, B. (Eds.), Sustainability, Accounting and Accountability (pp. 37-69). Abingdon, Oxon: Routledge.

Dyllick, T., \& Hockerts, K. (2002). Beyond the business case for corporate sustainability. Business strategy and the environment, 11(2), 130-141. http://onlinelibrary.wiley.com/doi/10.1002/bse.323/full

Edoho, F. M. (2008). Oil transnational corporations: corporate social responsibility and environmental sustainability. Corporate Social Responsibility and Environmental Management, 15(4), 210-222. http://onlinelibrary.wiley.com/doi/10.1002/csr.143/full

Emoyan, O. O. (2008). The oil and gas industry and the Niger Delta: Implications for the environment. Journal of Applied Sciences and Environmental Management, 12(3).

Eweje, G. (2006). Environmental costs and responsibilities resulting from oil exploitation in developing countries: The case of the Niger Delta of Nigeria. Journal of Business Ethics, 69, 27-56.

Fagbohun, O. (2007). Imperatives of Environmental Restoration Due to Oil Pollution in Nigeria. The Stellenbosch L. Rev., 18, 347. https://journals.co.za/content/ju_slr/18/2/EJC54624

Fleming, P. \& Jones, M. (2013). The End of Corporate Social Responsibility: Crisis \& Critique, London: Sage. http://www.tandfonline.com/doi/abs/10.1080/1051712X.2014.874262?journalCode=wbbm20

Folger, R., \& Cropanzano, R. (2001). Fairness theory: Justice as accountability. Advances in organizational justice, 1, 1-55.

Frederick, W. C., Dvis, K., \& Post, J. E. (1988). Business and Society: Corporate Strategy, Public Policy, Ethics. New York: McGraw-Hill.

Freeman, R. E. 1984. Strategic Management: A Stakeholder Approach, Marshfield: Pitman.

Frynas, J. G. (2000). Oil in Nigeria: Conflict and litigation between oil companies and village communities (Vol. 1). LIT Verlag Münster.

Frynas, J. G. (2009). Beyond corporate social responsibility-oil multinationals and social challenges. Cambridge University Press, Cambridge, UK. http://dx.doi.org/10.1017/

Frynas, J. G. (2012). Corporate social responsibility or government regulation? Evidence on oil spill prevention. Ecology and Society, 17(4), 4. http://dx.doi.org/10.5751/ES-05073-170404

Garriga, E., \& Melé, D. (2004). Corporate social responsibility: mapping the territory. Journal of Business Ethics, $53,51-71$.

George, R. T. (1999) International business ethics. In Frederick, R. E. (Ed.), A Companion to Business Ethics. Oxford: Blackwell Publishing.

Global Reporting Initiative. (2014). Sustainability Reporting Guidelines, available from http://www.globalreporting.org

Grant, R. W., \& Keohane, R. O. (2008). Accountability and abuses of power in world politics. American Political Science Review, 99(1), 29-43.

Gray, R. (1992) Accounting and Environmentalism: An Exploration of the Challenge of Gently Accounting for Accountability, Transparency, And Sustainability, Accounting, Organizations \& Society, 17(5), 399-425. https://doi.org/10.1016/0361-3682(92)90038-T

Gray, R., Adams, C. A., \& Owen, D. (2014). Accountability, Social Responsibility, and Sustainability: Accounting for Society and the Environment. Harlow, UK: Pearson Education Limited.

Gray, R., Owen, D., \& Adams, C. (1996). Accounting and Accountability: Changes and Challenges in Corporate Social and Environmental Reporting. Hemel Hempstead: Prentice Hall.

Hamann, R., Acutt, N., \& Kapelus P. (2003). Responsibility versus accountability? Interpreting the World Summit on Sustainable Development for a Synthesis Model of Corporate Citizenship. The Journal of Corporate Citizenship, 9.

Heal, G. (2005). Corporate social responsibility: An economic and financial framework. The Geneva papers on risk and insurance-Issues and practice, 30(3), 387-409.

Heugens, P. P., \& Kaptein, M. (2008). Contracts to communities: A processual model of organizational virtue. $\begin{array}{lllll}\text { Journal of } & \text { Management } & \text { Studies, } & 45(1), & \text { 100-1. }\end{array}$ 
http://onlinelibrary.wiley.com/doi/10.1111/j.1467-6486.2007.00738.x/full

Holliday, C. O., Jr, S. S., \& Watts, P. (2002). Walking the Talk: The Business Case for Sustainable Development. Sheffield, UK: Greenleaf Publishing.

Idemudia, U. (2007). Community perceptions and expectations: reinventing the wheels of corporate social responsibility practices in the Nigerian oil industry. Business and Society Review, 112(3), 369-405. http://onlinelibrary.wiley.com/doi/10.1111/j.1467-8594.2007.00301.x/full

Idemudia, U. (2008). Conceptualising the CSR and development debate. Journal of Corporate Citizenship, (29), 91-110

Idemudia, U. (2009). Assessing corporate-community involvement strategies in the Nigerian oil industry: An empirical analysis. Resources Policy, 34(3), 133-141. https://doi.org/10.1016/j.resourpol.2009.01.002

Jaffe, A. B., \& Palmer, K. (1997). Environmental regulation and innovation: a panel data study. Review of $\begin{array}{llll}\text { economics and } & \text { statistics, } & \text { 610-619), }\end{array}$ http://www.mitpressjournals.org/doi/abs/10.1162/003465397557196

Khalastchi, R., \& Ward, H. (1998). New instruments for sustainability: an assessment of environmental agreements under Community Law. Journal of Environmental Law, 10(2), 257-290. https://doi.org/10.1093/jel/10.2.257

Laplante, L. J., \& Spears, S. A. (2008). Out of the conflict zone: the case for community consent processes in the extractive sector. Yale Hum. Rts. \& Dev. LJ, 11, 69.

Lerner, J. S., \& Tetlock, P. E. (1999). Accounting for the effects of accountability. Psychological bulletin, 125(2), 255. http://psycnet.apa.org/doi/10.1037/0033-2909.125.2.255

López-Gamero, M. D., Molina-Azorín, J. F., \& Claver-Cortés, E. (2010). The potential of environmental regulation to change managerial perception, environmental management, competitiveness and financial performance. Journal of Cleaner Production, 18(10), 963-974. https://doi.org/10.1016/j.jclepro.2010.02.015

MacKay, F. (2004). Indigenous People's Right to Free, Prior and Informed Consent and the World Bank's Extractive Industries Review. Sustainable Development Law \& Policy, 4(2), 12.

Neugebauer III, G. P. (2003). Indigenous peoples as stakeholders: Influencing resource-management decisions affecting indigenous community interests in Latin America. NYUL Rev., 78, 1227.

Roht-Arriaza, N. (2001). The role of international actors in national accountability processes. The politics of memory: transitional justice in democratizing societies, 40-64.

Ross, M. L. (2004). How do natural resources influence civil war? Evidence from thirteen cases. International organization, 58(1), 35-67. https://doi.org/10.1017/S002081830458102X

Schedler, A. (1999). Conceptualising accountability. In Schedler, A., Diamond, L. \& Platter, M. F. (Eds.), The Self-Restraining State: Power and Accountability in New Democracies. Colorado: Lynne Reinner Publishers.

Simon, G. J., Powers, W. C., \& Gunnemann, P. J. (1993). The Responsibilities of Corporations and their Owners. In T. L. Beauchamp and N.E. Bowie (Eds.), Ethical Theory and Business. Englewood Cliffs, NJ: Prentice Hall, 61-65.

Stormer, F. (2003). Making the shift: moving from "ethics pays" to an inter-systems model of business. Journal of Business Ethics, 44, 279-289.

Suzuki, E., \& Nanwani, S. (2005). Responsibility of international organizations: the accountability mechanisms of multilateral development banks. Mich. J. Int'l L., 27, 177.

Turner, T. E., \& Brownhill, L. S. (2004). Why women are at war with Chevron: Nigerian subsistence struggles against the international oil industry. Journal of Asian and African studies, 39(1-2), 63-93. http://journals.sagepub.com/doi/abs/10.1177/0021909604048251

Unerman, J., \& O'Dwyer (2007). The Business Case for Regulation of Corporate Social responsibility and Accountability. Accounting Forum, 31, 332-353. https://doi.org/10.1016/j.accfor.2007.08.002

Utting, P. (2008). The struggle for corporate accountability. Development and Change, 39(6), 959-975. http://onlinelibrary.wiley.com/doi/10.1111/j.1467-7660.2008.00523.x/full

Waddock, S. A., \& Wettstein, F. (2005). Voluntary or mandatory: that is (not) the question: linking corporate 
citizenship to human rights obligations for business. Zeitschrift für Wirtschafts-und Unternehmensethik, 6(3), 304-320.

Wawryk, A. S. (2003). International environmental standards in the oil industry: improving the operations of transnational oil companies in emerging economies. Oil, Gas \& Energy Law Intelligence, 1(1).

Windsor, D. (2001). The future of corporate responsibility. International Journal of Organizational Analysis, 9 , $225-256$

\section{Copyrights}

Copyright for this article is retained by the author(s), with first publication rights granted to the journal.

This is an open-access article distributed under the terms and conditions of the Creative Commons Attribution license (http://creativecommons.org/licenses/by/4.0/). 